\title{
Workshop Kartu Kuartet dan Donasi Buku di Panti Asuhan Darul Ilmi Pekanbaru
}

\author{
Dewi Gulyla Hari ${ }^{1}$, Yasinda Oktariza*1,2, Muhammad Azhari Herli ${ }^{1}$ \\ ${ }^{1}$ Program Studi Farmasi, Universitas Muhammadiyah Riau \\ email: 1yla@umri.ac.id \\ ${ }^{2}$ Widyaiswara, Balai Pelatihan Kesehatan Batam, Kementerian Kesehatan RI \\ email: yasindaoktariza@gmail.com
}

\begin{abstract}
As young generation in the future, education must be provided properly to children from an early age. Education can be started by increasing children's reading interest because reading is a window to the world. The weak ability and interest in reading can affect the quality of learning in children during their education. Therefore, Program Kemitraan Masyarakat (PKM) aims to increase knowledge and children's interest in reading at Panti Asuhan Darul Ilmi Pekanbaru. The PKM program is carried out with three main activities, namely increasing reading interest through donating children's reading books, increasing children's knowledge through drug counseling and anti-drug abuse quartet card workshops, and evaluating reading interest using the observation method and evaluating the level of knowledge of the children using a questionnaire. Based on observations, children's book donation can increase children's interest in reading because the books given are in accordance with the age and needs of the children in the orphanage. Counseling and quartet card workshops also showed an increase in the average score between before and after the implementation of drug counseling and quartet card workshops. This shows that the children's reading interest and knowledge has increased after the implementation of this program.
\end{abstract}

Keywords: orphanage, reading interest, books, drug counseling, quartet card

\begin{abstract}
Abstrak
Sebagai penyambung generasi muda di masa yang akan datang, pendidikan harus diberikan dengan baik pada anak sejak dini. Pendidikan yang baik dapat dimulai dengan meningkatkan kemampuan dan minat baca anak karena membaca adalah jendela dunia. Lemahnya kemampuan dan minat baca anak dapat memengaruhi kualitas anak dalam mengikuti perkembangan ilmu pengetahuan dan informasi selama menempuh pendidikan. Maka dari itu, Program Kemitraan Masyarakat (PKM) ini bertujuan untuk dapat meningkatkan minat baca dan pengetahuan anak-anak di Panti Asuhan Darul Ilmi Pekanbaru. Program PKM dilakukan dengan tiga kegiatan utama yaitu peningkatan minat baca melalui donasi buku bacaan anak, peningkatkan pengetahuan anak melalui penyuluhan obat dan workshop kartu kuartet anti penyalahgunaan obat, serta evaluasi minat baca dengan metode observasi dan evaluasi tingkat pengetahuan anak-anak panti dengan menggunakan kuesioner. Berdasarkan hasil observasi, donasi buku bacaan anak dapat meningkatkan minat anak untuk membaca karena buku yang diberikan sesuai dengan usia dan kebutuhan anak-anak yang ada di panti asuhan. Penyuluhan dan workshop kartu kuartet juga menunjukkan adanya peningkatan skor rata-rata antara sebelum dan setelah pelaksanaan penyuluhan obat dan workshop kartu kuartet. Hal ini menunjukkan minat baca dan pengetahuan anak-anak panti asuhan mengalami kenaikan setelah penyelenggaraan program PKM ini.
\end{abstract}

Kata Kunci: panti asuhan, minat baca, buku, penyuluhan obat, kartu kuartet 


\section{PENDAHULUAN}

Hasil survei nasional yang dilakukan oleh Badan Pusat Statistik (BPS) tahun 2017 ditemukan 10,53 persen anak usia 517 tahun belum bisa membaca dan menulis atau buta huruf. Hasil survei nasional lainnya pada tahun 2015 menunjukkan bahwa pemuda yang melakukan kegiatan membaca dalam seminggu terakhir adalah sebesar 43,57 persen [1]. Hal ini menunjukkan budaya membaca dikalangan pemuda masih tergolong rendah. Sebuah penelitian juga mengungkapkan bahwa minat baca siswa kelas VI di salah satu Sekolah Dasar masih rendah dilihat dari jumlah kunjungan ke perpustakaan [2]. Berbagai usaha tetap harus dilakukan demi tercapainya kualitas SDM yang lebih baik.

Permasalahan yang sama juga ditemukan pada mitra Program Kemitraan Masyarakat (PKM) ini yaitu Panti Asuhan Darul Ilmi Pekanbaru. Panti asuhan yang baru berdiri tahun 2018 ini dikelola oleh pengelola panti dan telah mengasuh 27 orang anak dengan tingkat pendidikan yang bervariasi mulai dari belum sekolah, SD, SMP, dan SMA. Berdasarkan hasil wawancara dengan pengelola panti, terdapat lebih dari setengahnya yaitu 69,23 persen anak yang belum lancar membaca dari total keseluruhan anak dengan tingkat pendidikan sekolah dasar. Pengelola panti juga menyampaikan bahwa sebagian besar anak-anak panti yang telah lancar membaca memiliki minat baca yang rendah dan tidak terlalu beprestasi di sekolah.

Berdasarkan analisis situasi mitra maka beberapa poin permasalahan yang menjadi prioritas dalam pelaksanaan PKM ini dan telah disetujui oleh kedua belah pihak yaitu perlunya peningkatan fasilitas pendukung yang dapat menumbuhkan minat baca anak-anak di panti asuhan dan perlu dilakukan kegiatan yang menarik yang dapat menumbuhkan minat baca dan pengetahuan pada anak.
Kebiasaan membaca dapat ditingkatkan dengan beberapa cara yaitu tersedianya bahan bacaan yang menarik, bervariasi, mudah ditemukan, buku bacaan dapat memenuhi keinginan pembacanya [3], mempercantik koleksi buku pribadi, membentuk perpustakaan mini, mempercantik perpustakaan sekolah, kantor, ataupun perpustakaan nasional [4], dan lain-lain. Penelitian juga menunjukkan terdapat peningkatan minat baca, nilai hasil belajar, dan hasil portofolio siswa setelah pembelajaran menggunakan kartu kuartet [5]-[7]. Selain itu, penggunaan kartu kuartet memberikan pengaruh terhadap pengetahuan siswa sekolah dasar tentang penyalahgunaan obat [8].

Maka dari itu, Program Kemitraan Masyarakat ini bertujuan untuk menumbuhkan minat baca anak-anak melalui dua strategi yaitu donasi buku bacaan dan workshop bermain sambil membaca dengan menggunakan kartu kuartet untuk menarik minat anak. Permainan kartu kuartet diharapkan dapat menarik perhatian anak-anak untuk membaca sambil bermain sehingga secara tidak langsung dapat menambah pengetahuan anak. Program pengabdian ini diharapkan dapat memberikan manfaat bagi mitra di masa depan.

\section{METODE PENGABDIAN}

Pelaksanaan program pengabdian dilakukan dengan metode observasi dan pelaksanaan langsung di lapangan. Program PKM ini dilakukan selama 2 (dua) bulan dengan kegiatan utama yang dilakukan dalam 1 (satu) hari. Kegiatan pengabdian dilaksanakan pada tanggal 25 Desember 2020 di lokasi mitra yaitu Panti Asuhan Darul Ilmi Pekanbaru. Pelaksanaan program pengabdian bekerja sama dengan Himpuanan Mahasiswa Farmasi (HIMAFARM) UMRI. Program pengabdian dilakukan dengan beberapa tahapan yang telah disepakati oleh pelaksana pengabdian dan pengelola panti asuhan. 


\section{Analisis Situasi dan Permasalahan Mitra}

Analisis situasi dan permasalahan mitra dilakukan dengan metode wawancara langsung kepada pengelola panti asuhan pada tanggal 5 September 2019. Analisis dilakukan secara deskriptif berdasarkan hasil wawancara dan pengamatan langsung terhadap kondisi panti asuhan yang teramati di lapangan.

\section{Persetujuan Program}

Persetujuan program sebagai solusi untuk menyelesaikan permasalahan mitra dilakukan berdasarkan kesepakatan antara pelaksana pengabdian dan pengelola panti asuhan. Persetujuan tersebut dituangkan dalam bentuk Surat Pernyataan Kesediaan Kerjasama yang ditandatangani langsung oleh pengelola panti asuhan.

\section{Pelaksanaan Program}

Kegiatan yang akan dilakukan dalam PKM ini yaitu melengkapi fasilitas penunjang berupa hibah buku bacaan yang berasal dari dana internal pelaksanaan PKM serta donasi dari sukarelawan, dan workshop permainan kartu kuartet 5 set dengan topik "Edukasi Anti Penyalahgunaan Obat" dengan sasaran yaitu anak-anak panti asuhan yang telah bisa membaca dan memiliki minat baca yang rendah. Bagi anak-anak yang belum bisa membaca akan diarahkan untuk mengikuti kegiatan belajar sambil bermain dengan menggunakan buku donasi yang telah diberikan.

Pelaksanaan program terdiri dari beberapa tahapan. Tahapan persiapan yaitu mempersiapkan kebutuhan pengadaan buku dari program dan donasi buku/uang dari sukarelawan. Donasi buku dari sukarelawan dilakukan dengan menyebarkan poster secara daring serta mouth to mouth. Persiapan lainnya yaitu merancang dan mencetak design kartu kuartet dengan topik anti penyalahgunaan obat. Tahapan inti program dimulai dengan pembukaan, penyuluhan obat untuk anak sekolah, penyelenggaran workshop kartu kuartet dan belajar sambil bermain, evaluasi minat baca dengan metode observasi, evaluasi penerapan kartu kuartet dengan menggunakan kuesioner, dan diakhiri dengan acara penutupan.

\section{HASIL DAN PEMBAHASAN}

Mitra dalam usulan Program Kemitraan Masyarakat (PKM) ini adalah Panti Asuhan Darul Ilmi yang beralamat di jalan Rawasari I, Kelurahan Tangkerang Tengah, Pekanbaru. Panti asuhan baru berdiri tahun 2018 dan dikelola oleh seorang ibu asuh dengan empat orang yang membantu secara aktif dalam pengelolaannya. Beberapa orang yang berperan aktif tersebut adalah bendahara, sekretaris, dan penanggung jawab rumah tangga.

Panti asuhan telah mengasuh 27 orang anak dengan tingkat pendidikan yang bervariasi seperti yang tercantum pada Tabel 1. Terdapat 69,23 persen (9 orang) anak yang belum lancar membaca dari total keseluruhan anak dengan tingkat pendidikan sekolah dasar dan 44,44\% (12 orang) anak dari total keseluruhan yang sudah lancar membaca namun memiliki minat baca yang rendah. Hal ini menandakan bahwa diperlukan strategistrategi yang harus dilakukan untuk meningkatkan minat baca anak di panti asuhan.

Pada Program PKM ini dilakukan penyerahan bantuan berupa donasi buku bacaan layak baca, rak buku 4 tingkat, masker untuk anak-anak panti, dan sabun cuci tangan. Jumlah donasi buku layak baca yang diterima adalah sejumlah 56 buku sedangkan jumlah dana dan donasi yang terkumpul hingga tanggal 19 Desember 2020 adalah sejumlah Rp1.143.500,00 (satu juta seratus empat puluh tiga ribu lima ratus rupiah). 
Tabel 1 Data anak di Panti Asuhan Darul Ilmi Berdasarkan Hasil Wawancara dengan Pengelola Panti Tahun 2019

\begin{tabular}{lccl}
\hline \multicolumn{1}{c}{ Tingkat pendidikan } & Kelas & Jumlah Anak & \multicolumn{1}{c}{ Keterangan } \\
\hline Belum sekolah $(<5$ tahun $)$ & - & 6 & Belum lancar membaca \\
\hline \multirow{3}{*}{ Sekolah Dasar } & 1 & 2 & Belum lancar membaca \\
& 2 & 1 & Belum lancar membaca \\
& 3 & 3 & Belum lancar membaca \\
& 4 & 3 & Belum lancar membaca \\
\multirow{2}{*}{ Sekolah Menengah } & 5 & 3 & Sudah lancar membaca minat baca rendah \\
Pertama (SMP) & 6 & 1 & Sudah lancar membaca minat baca rendah \\
\hline \multirow{2}{*}{ Sekolah Menengah Atas } & 2 & 2 & Sudah lancar membaca minat baca rendah \\
(SMA) & 3 & 3 & Sudah lancar membaca minat baca rendah \\
& 2 & 0 & Sudah lancar membaca minat baca rendah \\
\hline
\end{tabular}

Seluruh dana yang terkumpul telah digunakan untuk belanja buku donasi yang telah diserahkan pada tanggal 25 Desember 2020. Penyerahan bantuan dan donasi dilakukan dengan menyertakan penandatanganan Berita Acara sebagai tanda bukti serah terima dan pelaksanaan pengabdian kepada Masyarakat di Panti Asuhan seperti pada gambar dibawah ini.

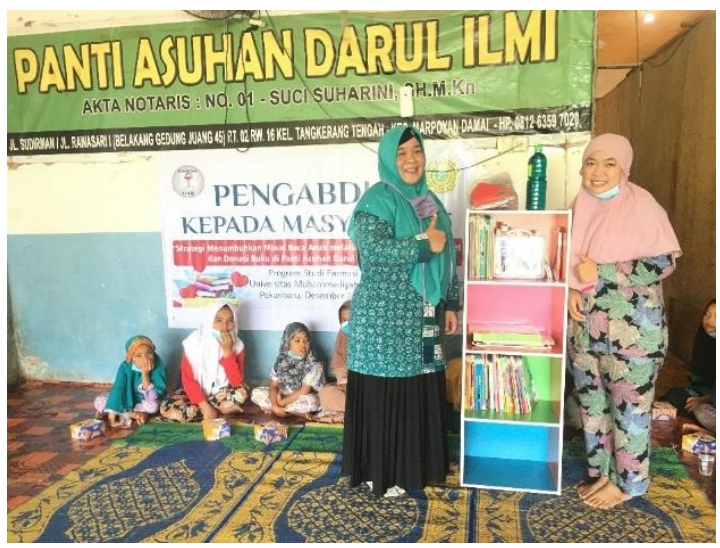

Gambar 1 Serah terima donasi

Buku donasi yang diserahkan terdiri dari buku-buku cerita anak, buku pengetahuan islami, buku belajar menghitung, buku belajar mewarnai, dan disertai dengan pensil warna untuk mendukung aktivitas anak-anak untuk mewarnai bagi yang belum bisa membaca.
Setelah penyerahan buku donasi terlihat bahwa anak-anak panti asuhan sangat semangat untuk membaca buku yang terlihat pada Gambar 2. Semoga bukubuku donasi ini dapat meningkatkan minat baca anak-anak di Panti Asuhan Darul Ilmi Pekanbaru. Ketersediaan koleksi buku bacaan yang sesuai dengan usia anak-anak terbukti dapat menumbuhkan rasa ingin tahu dan keinginan anak-anak panti untuk membaca maupun menggunakan buku tersebut [9], [10].

Pelaksanaan penyuluhan obat untuk anak-anak di panti asuhan dan workshop kartu kuartet dilaksanakan pada hari yang sama dengan serah terima donasi buku. Jumlah panitia pelaksana adalah 10 orang yang terdiri dari 3 orang dosen dan 7 orang mahasiswa farmasi perwakilan dari HIMAFARM UMRI. Jumlah anak-anak panti asuhan yang hadir pada pelaksanaan kegiatan dan telah mengisi daftar hadir adalah sejumlah 25 orang. Kegiatan penyuluhan obat disampaikan oleh Ibu apt. Dewi Gulyla Hari, M.S.Farm. Materi yang disampaikan pada penyuluhan obat adalah pengenalan tentang obat, penjelasan tentang cara pakai obat, dan penyuluhan tentang anti penyalahgunaan obat. Penyuluhan ini (Gambar 3) bertujuan 
untuk mengedukasi anak-anak panti dalam menggunakan maupun memilih obat.
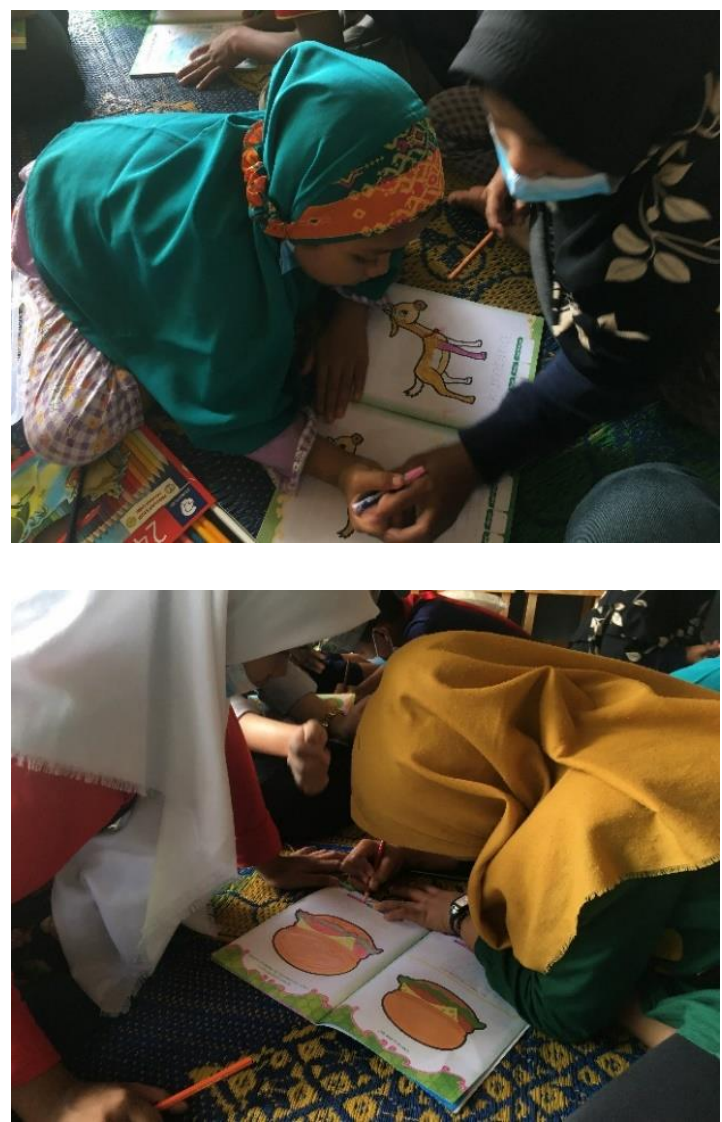

Gambar 2 Keseruan anak panti belajar sambil bermain

Workshop kartu kuartet penyalahgunaan obat (Gambar 4) dilakukan terhadap 11 orang anak-anak panti yang bisa membaca. Bagi anak-anak panti yang masih kecil atau belum bisa membaca dibimbing untuk melakukan kegiatan belajar mengenal benda-benda dan mewarnai. Workshop disertai dengan pencarian pemenang dari masing-masing grup dan pemberian hadiah.

Evaluasi pengetahuan anak-anak panti setelah kegiatan penyuluhan dan workshop kartu kuartet dilakukan dengan menyebarkan kuesioner sebelum dan setelah pelaksanaan kegiatan.

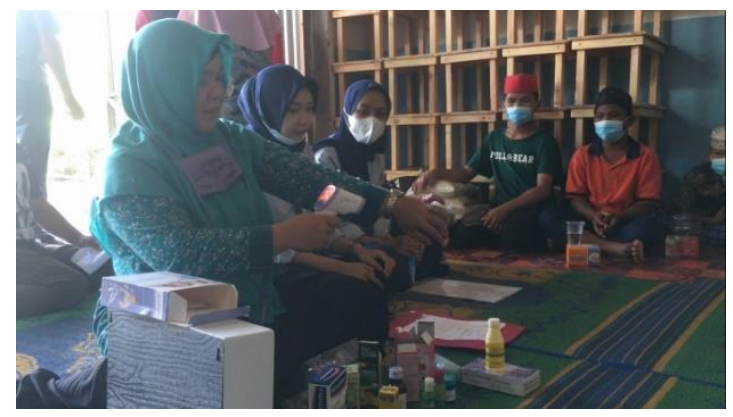

Gambar 3 Penyuluhan Obat
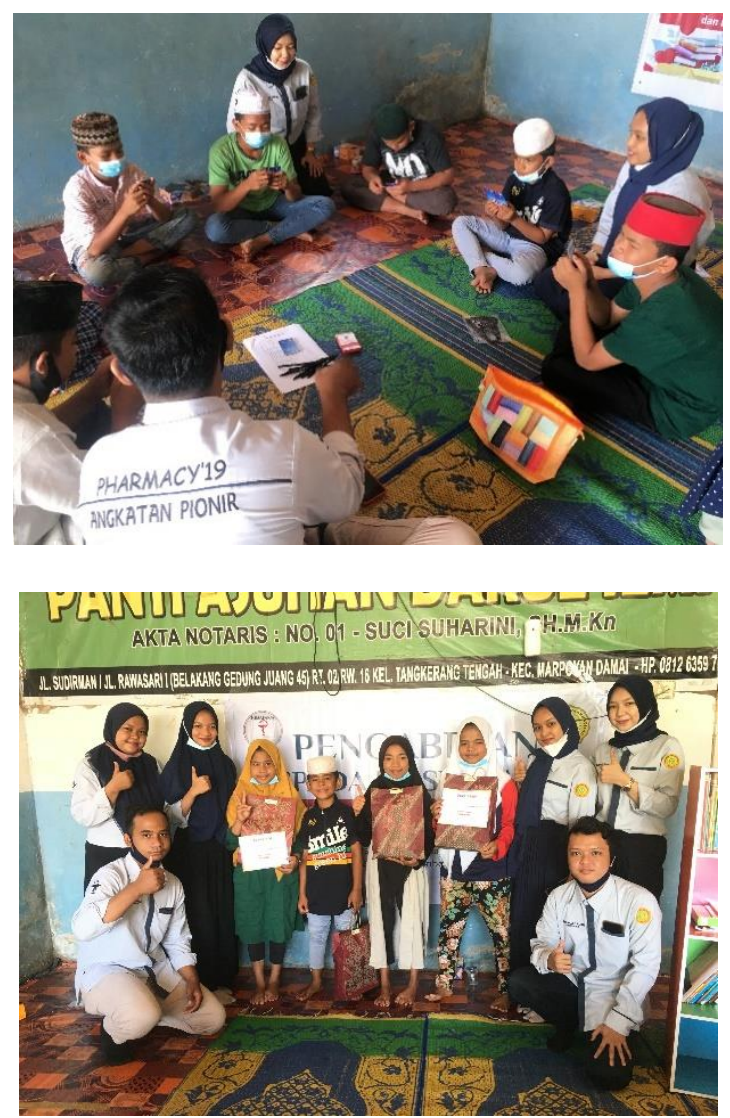

Gambar 4 Pelaksanaan workshop kartu kuartet

Berdasarkan hasil evaluasi yang tercantum pada Tabel 2 diperoleh bahwa terdapat peningkatan skor rata-rata antara sebelum dan setelah pelaksanaan penyuluhan obat dan workshop kartu kuartet. Hasil evaluasi ini mendukung penelitian sebelumnya yaitu penggunaan kartu kuartet memiliki pengaruh terhadap pengetahuan siswa sekolah dasar tentang penyalahgunaan obat. 
Tabel 2 Hasil evaluasi menggunakan kuesioer

\begin{tabular}{llcc}
\hline \multirow{2}{*}{ No. } & \multicolumn{1}{c}{ Nama } & \multicolumn{2}{c}{ Skor } \\
\cline { 3 - 4 } & & Sebelum & Sesudah \\
\hline 1 & Ezi Saputra & 90 & 100 \\
\hline 2 & Ilma & 90 & 100 \\
\hline 3 & Indra & 80 & 80 \\
\hline 4 & Lisa & 90 & 100 \\
\hline 5 & M. Ridoan & 80 & 90 \\
\hline 6 & Mhd. Ripai & 70 & 90 \\
\hline 7 & Mhd. Romadon & 50 & 100 \\
\hline 8 & M. Ismail & 90 & 100 \\
\hline 9 & Rindu & 90 & 100 \\
\hline 10 & Umar Soleh & 100 & 100 \\
\hline 11 & Zai Fina Sahida & 90 & 100 \\
\hline & Rata-rata skor & 83.64 & 96.36 \\
\hline
\end{tabular}

\section{SIMPULAN}

Kegiatan Program Pengabdian kepada Masyarakat ini terdiri dari donasi buku bacaan, penyuluhan obat, workshop kartu kuartet, dan evaluasi. Workshop kartu kuartet dilakukan terhadap 11 orang anakanak panti yang bisa membaca dan selebihnya diarahkan untuk belajar sambil bermain serta melakukan aktivitas mewarnai. Kegiatan PKM ini berjalan dengan lancar dan anak-anak panti terlihat sangat antusias dalam mengikuti kegiatan. Anak-anak panti asuhan terlihat bersemangat untuk membaca buku donasi dan menggunakan buku-buku untuk mewarnai. Kegiatan PKM ini juga dapat meningkatkan pengetahuan anak-anak panti tentang obat-obatan secara umum dan antipenyalahgunaan obat.

\section{UCAPAN TERIMAKASIH}

Ucapan terima kasih diberikan kepada Lembaga Penelitian dan Pengabdian kepada Masyarakat (LPPM) Universitas Muhammadiyah Riau atas pendanaan yang diberikan sehingga pengabdian ini dapat terlaksana dengan baik.

\section{DAFTAR PUSTAKA}

[1] Badan Pusat Statistik, Statistik Pemuda Indonesia 2015. Jakarta: Badan Pusat Statistik, 2015.

[2] I. N. Triatma, "Minat baca pada siswa kelas Vi Sekolah Dasar Negeri Delegan 2 Prambanan Sleman Yogyakarta," E-Jurnal Skripsi Progr. Stud. Teknol. Pendidik., vol. 5, no. 6, p. 167, 2016.

[3] E. Saepudin, "Tingkat Budaya Membaca Masyarakat," J. Kaji. Inf. Perpust., vol. 3, no. 2, pp. 271-282, 2015.

[4] N. U. Millah, "Meningkatkan minat baca." [Online]. Available: http://www.bpkp.go.id/pustakabpk p/index.php? $\mathrm{p}=$ tingkat minat baca. [Accessed: 06-Sep-2019].

[5] Karsono, Y. Sujana, J. Daryanto, and N. Yustinus, "Pada Siswa Sekolah Dasar," Mimb. Sekol. Dasar, vol. 1, no. April, pp. 43-49, 2014.

[6] R. I. Habiba, "Peningkatan Hasil Belajar Dengan Media Kartu Kwartet Dalam Keterampilan Menyusun Portofolio," Ilmu Pendidik. J. Kaji. Teor. dan Prakt. Kependidikan, vol. 2, no. 1, pp. 8591, 2017, doi: 10.17977/um027v2i12017p085.

[7] A. E. Hartanto, Sukarno, and Kuswadi, "Kartu kata bergambar pada anak kelompok B Tk Negeri pembina Surakarta tahun pelajaran 2013/2014," J. FKIP UNS, vol. 2, no. $1,2014$.

[8] Hannan, P. Wikaningtyas, and I. K. Adnyana, "Edukasi Anti Penyalahgunaan Obat Kepada Siswa SD Di Kota Palu Melalui Media Kartu Kuartet," J. Farm. Galen. (Galenika J. Pharmacy), vol. 5, no. 1, pp. 20-25, 2019, doi: 10.22487/j24428744.2019.v5.i1.11 933.

[9] O. : Periyeti, "Usaha Meningkatkan 
Minat Baca Mahasiswa," J. Pustaka Budaya, vol. 4, no. 1, p. 126837 , 2017.

[10] K. Suharmono, "Upaya Meningkatkan Minat Baca sebagai Sarana untuk Mencerdaskan Bangsa," J. Pena Indones., vol. 1, no. 1, pp. 79-95, 2015. 